\title{
Effect of Tiliacora triandra Leaf Extract on Glycemic Control in Mice with High Sugar Intake
}

(Kesan Ekstrak Daun Tiliacora triandra ke atas Kawalan Glisemik pada Tikus dengan Pengambilan Gula yang Tinggi)

\section{WACHIRYAH THONG-ASA*, PrachayAPORn PrASERTSUKSRI, ROMGASE SAKAMUla \& THEERAYUT NimnUAN}

\begin{abstract}
Prediabetes is associated with sugar-sweetened beverages and sugar-rich processed foods. High sugar intake (HSI), which is represented as save dose, may silently alter the glycemic control. The present study investigated the effect of HSI and Tiliacora triandra (TT21) leaf extract on the glycemic control in mice. Eighteen male ICR mice were divided into three groups of Control-HSI, HSI-TT300 and HSI-TT600 that received 4 weeks of $30 \%$ glucose with a vehicle of T. triandra leaf extract 300 and $600 \mathrm{mg} / \mathrm{kg}$, respectively. The blood glucose, serum insulin, glucose clearance, liver and muscle glycogen contents and tissue oxidative status were evaluated. The results showed that HSI increased the blood glucose (w2 and w3: $\mathrm{p}<0.05)$ and serum insulin levels (w3 and w4: $\mathrm{p}<0.05)$ with glucose intolerance (w4: 30,60 and 90 min, $\mathrm{p}<0.05)$. T. triandra leaf extract reduced the blood glucose and serum insulin and increased the glycogen content in the liver and muscle tissues $(\mathrm{p}<0.05)$. We concluded that HSI silently induced an alteration of the glycemic control in the normal mice, and the T. triandra leaf extract nurtured the glycemic control in the HSI mice by lowering the blood glucose and serum insulin and increasing the liver and muscle glycogen contents, which indicated an involvement of peripheral insulin sensitivity.
\end{abstract}

Keywords: Glucose clearance; glucose metabolism; glycemic control; high sugar intake; Tiliacora triandra

ABSTRAK

Pra-diabetes telah dikaitkan dengan pengambilan minuman manis dan makanan yang kaya dengan gula.Pengambilan gula tinggi (HSI) yang dikenali sebagai dos simpanan mungkin secara perlahan mengubah kawalan glisemik. Penyelidikan ini mengkaji kesan HSI dan ekstrak daun Tiliacora triandra (TT21) terhadap kawalan glisemik pada tikus. Lapan belas ekor tikus ICR jantan telah dibahagikan kepada 3 kumpulan, iaitu kawalan-HSI, HSI-TT300 dan HSITT600 yang menerima 30\% glukosa selama 4 minggu dengan ekstrak daun T. triandra 300 dan $600 \mathrm{mg} / \mathrm{kg}$ sebagai pembawa. Glukosa darah, serum insulin, pelepasan glukosa, kandungan glikogen pada hepar dan otot serta status oksidatif tisu telah dinilai. Hasil kajian menunjukkan bahawa HSI meningkatkan glukosa darah (w2 dan w3: $\mathrm{p}<0.05)$ dan tahap insulin serum (w3 dan w4: p<0.05) dengan intoleransi glukosa (w4: 30, 60 dan 90 min, p<0.05). Ekstrak daun T. triandra mengurangkan glukosa darah, insulin serum dan peningkatan kandungan glikogen dalam tisu hepar dan otot $(\mathrm{p}<0.05)$. Berdasarkan keputusan kajian, kesimpulan bahawa HSI secara perlahan mendorong perubahan kawalan glisemik pada tikus normal dan ekstrak daun T. triandra mengawal kawalan glisemik dalam tikus HSI dengan menurunkan glukosa darah, insulin serum dan peningkatan kandungan glikogen pada hepar dan otot yang menunjukkan penglibatan kepekaan insulin periferi.

Kata kunci: Kawalan glisemik; metabolisme glukosa; pelepasan glukosa; pengambilan gula yang tinggi; Tiliacora triandra

\section{INTRODUCTION}

The worldwide increase of metabolic disease prevalence is found in both developing and developed countries (Osei-Yeboah et al. 2017). In the Asia-Pacific region, the rapid increase in prevalence has been from $11.9 \%$ to $37.1 \%$ (Ranasinghe et al. 2017). A preference for sugarsweetened beverages and sugar-rich processed foods has increased dramatically and is regarded as the major risk for metabolic complications (Benetti et al. 2013), for instance metabolic syndromes, the complex disorder that refers to the clustering of central obesity, insulin resistance, impaired glucose tolerance, hypertension and dyslipidemia (Moreno-Fernandez et al. 2018). Dysregulation in the mechanisms implicated in glucose homeostasis can cause acute or chronic hyperglycemia and plays a major role in a variety of cell function deteriorations (Marcovecchio et al. 2011). Interestingly, prediabetes, a condition with abnormal high glucose concentrations below the cutoff for a diabetic diagnosis, is indicated in metabolic impairments (Succurro et al. 2009). Prolonged systemic high glucose concentrations result in a large number of organ and tissue damages. The major deteriorative mediator is the reactive oxygen species (ROS), which is a result of a variety of metabolic 
pathways. An increase of the glucose flux through the polyol pathways, increase of the advanced glycosylation end product (AGEs) formations and activation of their receptors, activation of the $\mathrm{PKC}$ isoforms, over-activity of the hexosamine pathways, and a decrease in the antioxidant defenses are indicated as the mechanisms of glucose toxicity (Fiorentino et al. 2013; Kawahito et al. 2009). ROS directly alters proteins, lipids, DNA and cellular transduction signaling pathways, which lead to irreversible oxidative modifications. Alteration of protein expression caused by ROS, such as the mitogen activated protein kinases (MAPKs), NF-kB, hypoxia induced factor I (HIF-I), and activator protein I (AP-I), has been reported (Shah \& Channon 2004). High glucose concentrations also aggravate endothelial cell dysfunction and is characterized by a reduction of nitric oxide (NO) production, hemodynamic deregulation, overproduction of growth factors, impaired fibrinolytic ability and enhanced permeability of the cell. These are found in both the macrovascular and microvascular and increase cardiovascular risks (Popov 2010).

Prevention of metabolic complications by the safest and most cost-effective option is dietary intervention with a lifestyle change impacting consumption. The studies have emphasized the use of food-derived compounds, natural ingredients, medicinal plants and herbs in metabolic balance and the prevention of diseases (Craig 1999; Yamaki et al. 2016). Preventive therapy with medicinal plants, along with omitting sugar-sweetened beverages and sugar-rich processed food, has gained attention nowadays. Maintenance and balance of the body metabolisms by using dietary intervention helps prolong cell function, increase cell viability and strengthen against the attack of disease. There are many plants that have medicinal properties and may be a benefit to use for dietary intervention (Durmuskahya \& Özturk 2013). Medicinal plants are mostly flavonoid-rich and have many bioactivities, including anti-inflammation, antioxidant, anti-diabetic and anticancer (Boonyawee et al. 2017). Tiliacora triandra leaves are used as an ingredient in Thai food have many benefits of traditional medicine. It is used to treat pyretic, malaria, inflammation, alcohol toxicities, diabetes, and oxidants (Phunchango et al. 2015; Sanya et al. 2012). The neuroprotective effect of the $T$. triandra leaf extract against ischemia-reperfusion injury has recently been reported (Thong-asa et al. 2017b). There are no acute or sub-chronic toxicological indications with this plant extract (Sireeratawong et al. 2008). As reported with the hypoglycemic activity in streptozotocin-induced diabetic rats of T. triandra (Katisart \& Rattana 2017), it is interesting to assess the effect of the T. triandra leaf extract on the glycemic control, especially in prediabetesprone conditions associated with our common with sugarsweetened diets. Therefore, the present study aimed to investigate the effect of a chronic high sugar intake (HSI) and the modulatory effect of $T$. triandra leaf extract on the glycemic control in mice.

\section{MATERIALS AND METHODS}

ANIMALS

A total of 18 male ICR mice of 12-weeks of age were obtained from the National Laboratory Animal Centre, Mahidol University, Salaya, Nakornprathom, Thailand. They were housed individually in standard-sized cages at a well-controlled room temperature $\left(24 \pm 2^{\circ} \mathrm{C}\right)$ and humidity $(55 \pm 10 \%)$ with a $12 \mathrm{~h} / 12 \mathrm{~h}$ light-dark cycle.

\section{PLANT EXTRACT}

The ethanolic extract from the leaves of T. triandra was provided by the Animal Toxicology and Physiology Specialty Research Unit (ATPSRU) in the form of a green powder (TT21). Total phenolic and flavonoid contents of the extract were $340.21 \mathrm{mg} \mathrm{GAE} / \mathrm{g}$ and $231.29 \mathrm{mg} \mathrm{QE} / \mathrm{g}$, respectively (Thong-asa et al. 2017b).

\section{EXPERIMENTAL PROTOCOL}

The experimental protocol was approved by the Animal Ethics Committee, Kasetsart University Research and Development Institute (KURDI), Kasetsart University, Bangkok, Thailand (ID\#ACKU04459). First of all, the data from all mice were collected as a baseline, i.e. body weight, blood glucose level, serum insulin level, and an oral glucose tolerance test (OGTT). $24 \mathrm{~h}$ later, all animals were fed with a $30 \%$ glucose in drink water as the high sugar intake (HSI) and standard food (082G) (Ehsanifard et al. 2017). Mice were divided into three groups with six mice of each: Control-HSI, HSI-TT300 and HSI-TT600. Animals in the Control-HSI group received only the vehicle $(10 \%$ Tween 80). Animals in HSI-TT300 and HSI-600 received the T. triandra leaf extract 300 and $600 \mathrm{mg} / \mathrm{kg}$, respectively (Thong-asa \& Laisangunngam 2018; Thong-Asa et al. 2017a). Administrations were given continuously for 4 weeks. The body weight and a blood draw from the tail vein were collected every week. Animals were sacrificed at the fourth week, and organ tissues were collected for biochemical analysis of the oxidative status and glycogen content.

\section{ORAL GLUCOSE TOLERANCE TEST}

After $6 \mathrm{~h}$ of fasting, all mice were subjected to an OGTT by gavage with glucose $2 \mathrm{~g} / \mathrm{kg}$ of body weight. Blood was collected from the tail vein at the time of $0,30,90$ and $120 \mathrm{~min}$ after the glucose challenge to determine the blood glucose level by using the Easy G blood glucose monitoring system (Nagy \& Einwallner 2018).

\section{SERUM INSULIN DETERMINATION}

After blood collection, the blood was allowed to clot for 15-30 min at room temperature. The clot was removed by centrifuging at $1,000-2,000 \mathrm{~g}$ for $10 \mathrm{~min}$ in a refrigerated centrifuge, and the supernatant was collected as serum. The serum insulin levels were measured by an enzyme 
immunoassay (Mouse ELISA kits, EZRMI-13K, Merck, Millipore).

\section{BIOCHEMICAL ANALYSIS}

The organ tissues of the brain, liver, heart, lung, stomach, kidney, and testes were collected for biochemical analysis of the total protein (Lowry et al. 1951), calcium (Spare 1964), malondialdehyde (MDA), superoxide dismutase (SOD), and catalase (CAT) and for indexing the organ oxidative status (Sakamula \& Thong-Asa 2018).

\section{PERIODIC ACID SCHIFF METHOD (PAS)}

The liver and muscle tissues were processed for the PAS assessment of the glycogen content. Briefly, tissues were processed by embedding in paraffin and cutting into $5 \mu \mathrm{m}$ with a microtome. Five slides from each animal were selected. Tissue sections were processed in distilled water, treated with periodic acid for 5 min followed by distilled water, incubated with Schiff's reagent for 15 min and washed in running tap water for $10 \mathrm{~min}$. Tissue sections were then rinsed in increasing concentrations of alcohol (70,80,95 and 100\%), cleared in xylene and mounted as usual. Non-overlapping images in 5 regions of each slide were used. Image analysis for the liver and muscle glycogen was PAS positive area with diastase subtraction and represented as \% area of PAS positive using NIH Image $\mathrm{J}$.

\section{STATISTICAL ANALYSIS}

Data analysis using one-way analysis of variance (ANOVA) followed by Fisher's PLSD post hoc test with $p<0.05$ was accepted.

\section{RESULTS AND DISCUSSION}

Four weeks of HSI did not induce significant changes of body weight and glucose intake. The highest blood glucose level was in the Control-HSI with a significant difference from the HSI-TT600 at the second and third week of HSI $(p<0.05$, Figure 1(b)). The significant difference of blood glucose levels between the Control-HSI and HSI-TT300 were found later at the third week of HSI $(p<0.05$, Figure 1(d)). Serum insulin in the Control-HSI group was increased from the third week of HSI, and a significant difference was found at the third and fourth week of HSI when compared to HSITT600 ( $p<0.05$, Figure $1(\mathrm{~d}))$. The organ tissues' oxidative status determined by calcium, MDA, SOD and CAT levels were not different among the tissues (Table 1).

The oral glucose tolerance test clearly indicated an alteration of the glycemic control in the chronic HSI mice. The baseline OGTT showed no difference in the glucose

TABLE 1. Biochemical analysis of organ tissues oxidative status

\begin{tabular}{|c|c|c|c|c|}
\hline Organs / groups & $\begin{array}{l}\text { Calcium } \\
(\mathrm{mEq} / \mathrm{L})\end{array}$ & $\begin{array}{c}\text { MDA } \\
(\mu \mathrm{M} / \mathrm{mg} \text { protein })\end{array}$ & $\begin{array}{c}\text { SOD } \\
\text { (U/mg protein) }\end{array}$ & $\begin{array}{c}\text { CAT } \\
\text { (U/mg protein) }\end{array}$ \\
\hline \multicolumn{5}{|l|}{ Brain } \\
\hline Control-HSI & $1.381 \pm 0.091$ & $0.317 \pm 0.024$ & $0.083 \pm 0.003$ & $5.502 \pm 3.105$ \\
\hline HSI-TT300 & $1.106 \pm 0.111$ & $0.318 \pm 0.035$ & $0.091 \pm 0.011$ & $3.660 \pm 1.805$ \\
\hline HSI-TT600 & $1.575 \pm 0.055$ & $0.305 \pm 0.001$ & $0.054 \pm 0.003$ & $1.989 \pm 1.105$ \\
\hline \multicolumn{5}{|l|}{ Liver } \\
\hline Control-HSI & $2.299 \pm 0.489$ & $0.270 \pm 0.040$ & $0.055 \pm 0.021$ & $8.460 \pm 1.148$ \\
\hline HSI-TT300 & $2.778 \pm 0.196$ & $0.358 \pm 0.053$ & $0.053 \pm 0.023$ & $6.772 \pm 1.602$ \\
\hline HSI-TT600 & $2.079 \pm 0.406$ & $0.386 \pm 0.067$ & $0.026 \pm 0.007$ & $4.855 \pm 1.140$ \\
\hline \multicolumn{5}{|l|}{ Lung } \\
\hline Control-HSI & $2.268 \pm 0.274$ & $0.194 \pm 0.064$ & $0.062 \pm 0.013$ & $5.579 \pm 2.144$ \\
\hline HSI-TT300 & $1.937 \pm 0.219$ & $0.246 \pm 0.031$ & $0.061 \pm 0.022$ & $7.953 \pm 2.728$ \\
\hline HSI-TT600 & $1.901 \pm 0.186$ & $0.180 \pm 0.156$ & $0.059 \pm 0.014$ & $6.954 \pm 1.644$ \\
\hline \multicolumn{5}{|l|}{ Heart } \\
\hline Control-HSI & $1.631 \pm 0.212$ & $0.291 \pm 0.094$ & $0.040 \pm 0.012$ & $3.813 \pm 1.988$ \\
\hline HSI-TT300 & $1.713 \pm 0.099$ & $0.158 \pm 0.056$ & $0.042 \pm 0.007$ & $3.573 \pm 1.687$ \\
\hline HSI-TT600 & $1.820 \pm 0.146$ & $0.210 \pm 0.147$ & $0.036 \pm 0.015$ & $4.212 \pm 1.112$ \\
\hline \multicolumn{5}{|l|}{ Kidney } \\
\hline Control-HSI & $2.498 \pm 0.131$ & $0.061 \pm 0.003$ & $0.054 \pm 0.016$ & $7.571 \pm 0.914$ \\
\hline HSI-TT300 & $1.952 \pm 0.159$ & $0.043 \pm 0.033$ & $0.053 \pm 0.018$ & $9.713 \pm 3.282$ \\
\hline HSI-TT600 & $1.758 \pm 1.146$ & $0.069 \pm 0.017$ & $0.057 \pm 0.005$ & $6.058 \pm 1.458$ \\
\hline \multicolumn{5}{|l|}{ Stomach } \\
\hline Control-HSI & $1.713 \pm 0.121$ & $0.028 \pm 0.003$ & $0.074 \pm 0.008$ & $3.534 \pm 0.863$ \\
\hline HSI-TT300 & $1.962 \pm 0.210$ & $0.071 \pm 0.008$ & $0.069 \pm 0.007$ & $3.363 \pm 0.988$ \\
\hline HSI-TT600 & $1.855 \pm 0.137$ & $0.152 \pm 0.072$ & $0.072 \pm 0.003$ & $5.698 \pm 0.579$ \\
\hline \multicolumn{5}{|l|}{ Testis } \\
\hline Control-HSI & $1.698 \pm 0.212$ & $0.245 \pm 0.080$ & $0.052 \pm 0.017$ & $3.198 \pm 0.688$ \\
\hline HSI-TT300 & $2.064 \pm 0.188$ & $0.021 \pm 0.015$ & $0.035 \pm 0.100$ & $4.615 \pm 1.892$ \\
\hline HSI-TT600 & $2.135 \pm 0.362$ & $0.143 \pm 0.083$ & $0.039 \pm 0.011$ & $5.891 \pm 1.657$ \\
\hline
\end{tabular}


tolerance (Figure 1(e)) in all mice, while the fourth week of HSI represented a significant glucose intolerance in the Control-HSI group ( $p<0.05$, Figure 1(f)). The T. triandra leaf extract significantly prevented an alteration of the glycemic control in HSI-TT300 and HSI-TT600 $(p<0.05$, Figure 1(f)). The significant difference was found at 30 , 60 and 90 min after the glucose challenge.

The glycogen contents in the liver and muscle showed the same trend of increase by the T. triandra treated groups, and the high dose T. triandra treated group (HSI-TT600) showed a significant increase in the glycogen content in the liver and muscle tissues compared with Control-HSI $(p<0.05$, Figures 2-3).

Prediabetes prone, which is represented by a chronic increase of blood glucose levels but does not reach the diabetic diagnosis, is associated with sugar-sweetened beverages and sugar-rich processed foods. Chronic high concentrations of glucose in the blood can lead to an alteration of glycemic control in normal mice. We found that the HSI mice showed an alteration of glycemic control represented by glucose intolerance after 4 weeks of high glucose intake. Biochemical analysis of the organ tissues did not depict significant oxidative stress in the HSI mice. However, the blood glucose level and serum insulin were increased since the second and third week of HSI, respectively. This is a sign of insulin resistance that occurs in prediabetes. Glycemic controls are the maintaining of normal blood glucose range with neuroendocrine controlling of glucose metabolism. This consist of the balancing of glucose absorption from the gut, tissue utilization and the endogenous production of glucose (Kawahito et al. 2009). The present study found a lower glycogen content in the liver and muscle tissues in HSI mice than the T.triandra treated mice. Both low and high doses of $T$. triandra leaf extract exhibited an increase of glycogen storage in the liver and muscle tissues, though the significant difference was found only in the high dose. These implicated an alteration of the glycemic control in HSI mice can be prevented by T. triandra leaf extract. The study in streptozotocin-induced diabetic rats has found that $T$. triandra extract can reduce the elevated blood glucose, serum insulin, serum leptin, serum monocyte chemoattractant protein-1 (MCP-1), serum tumor necrosis factor (TNF)-alpha, serum MDA and triglyceride (TG) and indicate antioxidant and hypoglycemic activities of $T$. triandra leaf extract (Katisart \& Rattana 2017). The blood glucose level was lowered together with the high preference of glucose intake in the T. triandra treated mice. This may involve a bitter taste of the extract that induces a preference to the glucose. Higher glucose preference in the T. triandra treated groups did not induce an increase of blood glucose levels and serum insulin when compared to the Control-HSI group, and alteration of the glycemic control appeared at the fourth week of his was not found in T. triandra treated mice.
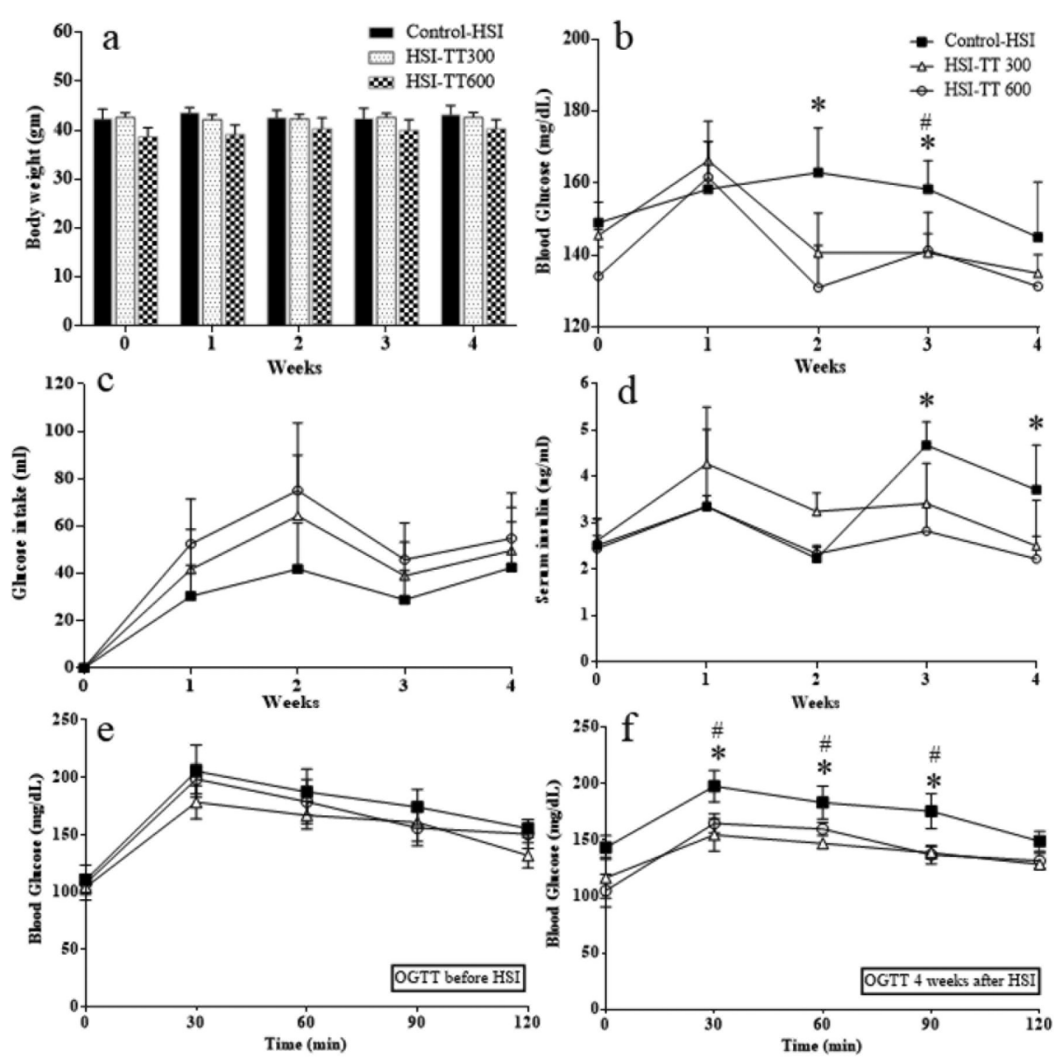

FIGURE 1. Body weight (a), blood glucose (b), glucose intake (c), serum insulin (d), oral glucose tolerance test (OGTT) before high sugar intake (HSI) (e), and OGTT 4 weeks after HIS (f). \# indicates significant difference compare between Control-HSI and HSI-TT300. * indicates significant difference compare between Control-HSI and HSI-TT600 


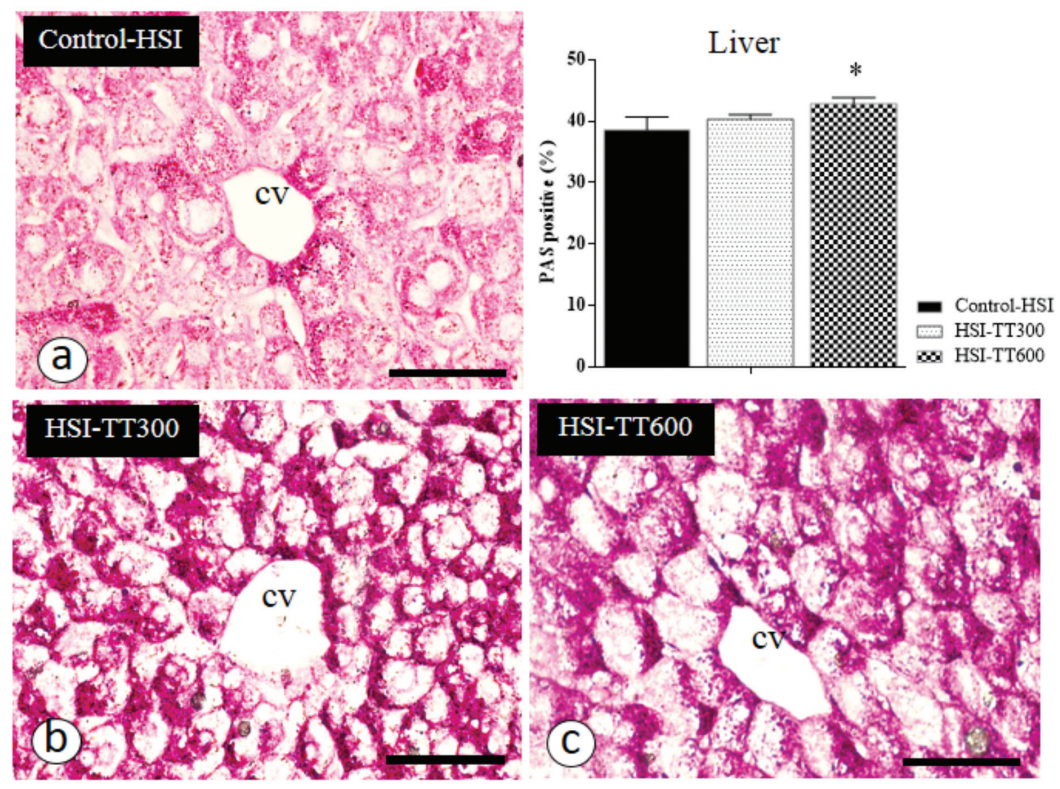

FIGURE 2. Histological illustration of mice liver with PAS staining, $400 \times$ of magnification with $50 \mu \mathrm{m}$ bars, $\mathrm{cv}=$ central vein. Histogram shows relative glycogen content represented by the percentage of PAS positive $(\%$ area). *indicates significant difference from Control-HSI

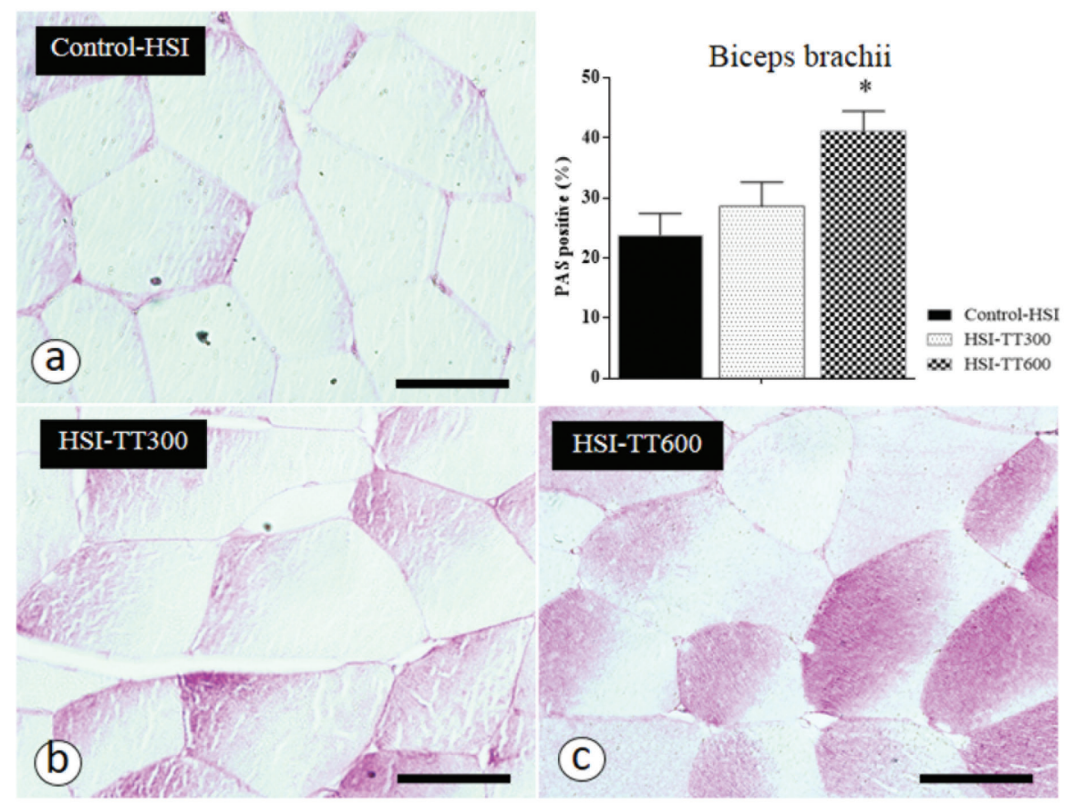

FIGURE 3. Histological illustration of mice muscle (biceps brachii), 400 $\times$ of magnification with PAS staining with $50 \mu \mathrm{m}$ bars. Histogram shows relative glycogen content represented by the percentage of PAS positive $(\%$ area). *indicates significant difference from Control-HSI

Maintenance of the glycemic control is associated with the glycogen content in the liver and muscle tissues in the present study. Although the glycogen content in the liver is indicated as a major source of glucose in the glycemic control rather than in muscles (Kasuga et al. 2003), the present study found a higher level of glycogen content in both the liver and muscle tissues in the $T$. triandra treated mice. Glycogen/glucose homeostasis is mainly regulated by two key enzymes, glycogen phosphorylase (GP) and glycogen synthase (GS). The key enzyme for glycogen breakdown is GP, which converts glycogen into glucose-1-phosphase and can be inhibited by flavonoids (Jakobs et al. 2006). High amounts of flavonoid content in the T. triandra leaf extract (Thongasa et al. 2017b) may have an inhibitory effect on GP and results in a high glycogen content in the T. triandra treated mice. In addition, flavonoids have been found to increase the glucokinase level that promotes glycogen synthesis 
(Chen et al. 2015), this may facilitate glycogen storage in the T.triandra treated mice as well.

The liver and skeletal muscle glycogen contents are reduced in type 2 diabetes (Shulman et al. 1990), in mice the muscle glycogen content is only about $10 \%$ compared to human muscle (Hribal et al. 2002). A greater effect on glucose tolerance of liver glycogen reduction than dose of muscle are indicated (Kasuga et al. 2003). In the present study, the maintenance of blood glucose in the T. triandra treated mice may involve the increase of peripheral insulin sensitivity. A reported indicated the increase of serum adiponectin in T.triandra extract treated mice (Naowaboot \& Chularojmontri 2017). Augmentation of adiponectin in systemic circulation is associated with the increase of peripheral insulin sensitivity (Pajvani \& Scherer 2003). Besides glycogen storage and the release of glucose from the liver in blood glucose control, the intestinal absorption is also involved. Interference of the intestinal absorption of glucose is found on plant fibers and flavonoid consumptions. A report indicated the intestinal facilitated glucose transporter recognizes a variety of flavonoids, and GLUT2, which is responsible for the glucose transport, is inhibited by dose dependent flavonoids as well (Chen et al. 2007). Therefore, flavonoid-rich T. triandra leaf extract maintains glucose homeostasis via the reduction of glycogen breakdown, promotion of glycogen synthesis, and increased insulin sensitivity (Vinayagam \& Xu 2015). A high preference of glucose intake with the lowest blood glucose level and serum insulin, as well as the highest glycogen content that were found in HIS with the high dose $T$. triandra treated mice indicated a nurturing effect of $T$. triandra on the glycemic control, involving improvement of glucose clearance, inhibition of glycogen breakdown, promoting of glycogen synthesis, inhibition of glucose intestinal absorption, and increased peripheral insulin sensitivity.

Further studies are needed for confirmation of cellular and molecular level effects of T. triandra extract on the glycemic control mechanism.

\section{CONCLUSION}

Effect of the T. triandra leaf extract on the glycemic control involves improvement of glucose clearance, inhibition of glycogen breakdown, promotion of glycogen synthesis, inhibition of glucose intestinal absorption, and increased peripheral insulin sensitivity.

\section{ACKNOWLEDGEMENTS}

This study was supported by grants from the Department of Zoology and Faculty of Science, Kasetsart University.

\section{REFERENCES}

Benetti,E., Mastrocola, R., Rogazzo, M., Chiazza, F.,Aragno, M., Fantozzi, R., Collino, M., \& Minetto, M.A. 2013. High sugar intake and development of skeletal muscle insulin resistance and inflammation in mice: A protective role for PPAR- delta agonism. Mediators Inflamm. 2013: 509502.

Boonyawee, N., Chaowanee, W., Paweena, P. \& Supantitra, C. 2017. Flavonoid component determination and apoptotic induction evaluation of Houttuynia cordata thunb extract on human acute leukemic cells. Med.\& Health Dec. 12(2): 193-201.

Chen, C.H., Hsu, H.J., Huang, Y.J. \& Lin, C.J. 2007. Interaction of flavonoids and intestinal facilitated glucose transporters. Planta Med. 73(4): 348-354.

Chen, J., Mangelinckx, S., Adams, A., Wang, Z.T., Li, W.L. \& De Kimpe, N. 2015. Natural flavonoids as potential herbal medication for the treatment of diabetes mellitus and its complications. Nat. Prod. Commun. 10(1): 187-200.

Craig, W.J. 1999. Health-promoting properties of common herbs. The American Journal of Clinical Nutrition 70(3): 491s-499s.

Durmuskahya, C. \& Özturk, M. 2013. Ethnobotanical survey of medicinal plants used for the treatment of diabetes in Manisa, Turkey. Sains Malaysiana 42(10): 1431-1438.

Ehsanifard, Z., Mir-Mohammadrezaei, F., Safarzadeh, A. \& Ghobad-Nejhad, M. 2017. Aqueous extract of Inocutis levis improves insulin resistance and glucose tolerance in high sucrose-fed Wistar rats. J. Herbmed. Pharmacol. 6(4): 160-164.

Fiorentino, T.V., Prioletta, A., Zuo, P. \& Folli, F. 2013. Hyperglycemia-induced oxidative stress and its role in diabetes mellitus related cardiovascular diseases. Curr. Pharm. Des. 19(32): 5695-5703.

Hribal, M.L., Oriente, F. \& Accili, D. 2002. Mouse models of insulin resistance. Am.J.Physiol.Endocrinol. Metab. 282(5): 977-981.

Jakobs, S., Fridrich, D., Hofem, S., Pahlke, G. \& Eisenbrand, G. 2006. Natural flavonoids are potent inhibitors of glycogen phosphorylase. Molecular Nutrition \& Food Research 50(1): 52-57.

Kasuga, M., Ogawa, W. \& Ohara, T. 2003. Tissue glycogen content and glucose intolerance. Journal of Clinical Investigation 111(9): 1282-1284.

Katisart, T. \& Rattana, S. 2017. Hypoglycemic activity of leaf extracts from Tiliacora triandra in normal and streptozotocininduced diabetic rats. Pharmacogn. J. 9(5): 621-625.

Kawahito, S., Kitahata, H. \& Oshita, S. 2009. Problems associated with glucose toxicity: Role of hyperglycemia-induced oxidative stress. World J. Gastroenterol. 15(33): 4137-4142.

Lowry, O.H., Rosebrough, N.J.,Lewis, F.A. \& Randall, R.J. 1951. Protein measurement with the Folin phenol reagent. J. Biol. Chem. 193(1): 265-275.

Marcovecchio, M.L., Lucantoni, M. \& Chiarelli, F. 2011. Role of chronic and acute hyperglycemia in the development of diabetes complications. Diabetes Technol. Ther. 13(3): 389-394.

Moreno-Fernandez, S., Garces-Rimon, M., Gonzalez, C., Uranga, J.A., Lopez-Miranda, V., Vera, G. \& Miguel, M. 2018. Pepsin egg white hydrolysate ameliorates metabolic syndrome in high-fat/high-dextrose fed rats. Food Funct. 9(1): 78-86.

Nagy, C. \& Einwallner, E. 2018. Study of in vivo glucose metabolism in high-fat diet-fed mice using Oral Glucose Tolerance Test (OGTT) and Insulin Tolerance Test (ITT). J. Vis. Exp. 131: e56672. doi: 10.3791/56672.

Naowaboot, J. \& Chularojmontri, L. 2017. Effects of Tiliacora triandra leaf water extract in high-fat diet fed mice. J. Med. Assoc. Thai. 100(5): 78-84. 
Osei-Yeboah, J., William, K.B.A., Owiredu, G.K.N., Lokpo, S.Y., Gyamfi, J., Allotey, E.A., Aduko, R.A., Noagbe, M. \& Attah, F.A. 2017. The prevalence of metabolic syndrome and its components among people with Type 2 diabetes in the Ho municipality, Ghana: A cross-sectional study. International Journal of Chronic Diseases 2017: 8765804.

Pajvani, U.B. \& Scherer, P.E. 2003. Adiponectin: Systemic contributor to insulin sensitivity. Curr. Diab. Rep. 3(3): 207-213.

Phunchango, N., Wattanathorn, J. \& Chaisiwamongkol, K. 2015. Tiliacora triandra, an anti-intoxication plant, improves memory impairment, neurodegeneration, cholinergic function, and ocidative stress in hippocampus of ethanol dependence rats. Oxidative Medicine and Cellular Longevity 2015: 918426.

Popov, D. 2010. Endothelial cell dysfunction in hyperglycemia: Phenotypic change, intracellular signaling modification, ultrastructural alteration, and potential clinical outcomes. International Journal of Diabetes Mellitus 2(3): 189-195.

Ranasinghe, P., Mathangasinghe, Y., Jayawardena, R., Hills, A.P. \& Misra, A. 2017. Prevalence and trends of metabolic syndrome among adults in the Asia-Pacific region: A systematic review. BMC Public Health 17(1): 101.

Sakamula, R. \& Thong-Asa, W. 2018. Neuroprotective effect of p-coumaric acid in mice with cerebral ischemia reperfusion injuries. Metab. Brain Dis. 33(3): 765-773.

Shah, A.M. \& Channon, K.M. 2004. Free radicals and redox signalling in cardiovascular disease. Heart 90(5): 486-487.

Shulman, G.I., Rothman, D.L., Jue, T., Stein, P., DeFronzo, R.A. \& Shulman, R.G. 1990. Quantitation of muscle glycogen synthesis in normal subjects and subjects with non-insulindependent diabetes by $13 \mathrm{C}$ nuclear magnetic resonance spectroscopy. N. Engl.J. Med. 322(4): 223-228.

Sireeratawong, Seewaboon, Nirush Lertprasertsuke, Umarat Srisawat, Amornat Thuppia, Anongnad Ngamjariyawat, Nadthaganya Suwanlikhid \& Kanjana Jaijoy. 2008. Acute and subchronic toxicity study of the water extract from Tiliacora triandra (Colebr.) diels in rats. Songklanakarin J. Sci. Technol. 30(5): 611-619.

Spare, P.D. 1964. A stable murexide reagent for the estimation of calcium in micro quantities of serum. Clinical Chemistry 10(8): 726-729.

Succurro, E., Marini, M.A., Arturi, F., Grembiale, A., Lugara, M., Andreozzi, F., Sciacqua, A., Lauro, R., Hribal, M.L., Perticone, F. \& Sesti, G. 2009. Elevated one-hour post-load plasma glucose levels identifies subjects with normal glucose tolerance but early carotid atherosclerosis. Atherosclerosis 207(1): 245-249.
Sanya Sureram, Sarath P.D. Senadeera, Poonpilas Hongmanee, Chulabhorn Mahidol, Somsak Ruchirawat \& Prasat Kittakoop. 2012. Antimycobacterial activity of bisbenzylisoquinoline alkaloids from Tiliacora triandra against multidrug-resistant isolates of Mycobacterium tuberculosis. Bioorganic \& Medicinal Chemistry Letters 22(8): 2902-2905.

Thong-Asa, W., Tumkiratiwong, P., Bullangpoti, V., Kongnirundonsuk, K. \& Tilokskulchai, K. 2017. Tiliacora triandra (Colebr.) Diels leaf extract enhances spatial learning and learning flexibility, and prevents dentate gyrus neuronal damage induced by cerebral ischemia/reperfusion injury in mice. Avicenna J. Phytomed. 7(5): 389-400.

Thong-asa, W. \& Laisangunngam, H. 2018. Enhancing effect of Tiliacora triandra leaves extract on spatial learning, memory and learning flexibility as well as hippocampal choline acetyltransferase activity in mice. Avicenna Journal of Phytomedicine 8(4): 380-388.

Vinayagam, R. \& Baojun, X. 2015. Antidiabetic properties of dietary flavonoids: A cellular mechanism review. Nutrition \& Metabolism 12(1): 60.

Yamaki, J., Kalyan, C., Nagulapalli, V., Animesh, M., Piyali, B. \& Bishayee, A. 2016. Health-promoting and disease-preventive potential of Trianthema portulacastrum Linn. (Gadabani) An Indian medicinal and dietary plant. Journal of Integrative Medicine 14(2): 84-99.

Wachiryah Thong-asa*, Romgase Sakamula \& Theerayut Nimnuan

Animal Toxicology and Physiology Specialty Research Unit (ATPSRU)

Department of Zoology

Faculty of Science

Kasetsart University, Bangkok

Thailand

Prachayaporn Prasertsuksri

Department of Anatomy

Faculty of Science

Mahidol University, Bangkok

Thailand

*Corresponding author; email: fsciwyth@ku.ac.th

Received: 4 April 2019

Accepted: 11 June 2019 